\title{
Leprosy in Bangladesh, 1984-88
}

\author{
Agha Masood Choudhury \\ Leprosy Control Institute and Hospital, \\ Mohakhali, Dhaka, Bangladesh.
}

(Received for publication: July 31,1991)

key words : Epidemiology, Leprosy, Bangladesh

\section{Summary}

A total of 2517 patients with leprosy were studied in Leprosy Control Institute and Hospital, Mohakhali, Dhaka, during the period 1984-1988. Among the total cases, 1891 (75.1\%) were male and $626(24.9$ $\%)$ were female. The male to female ratio was $3: 1$. The age groups comprised $185(7.4 \%)$, below 15 years and $2332(92.6 \%), 15$ years and over. Most of the cases were diagnosed by clinical examination and classified as Indeterminate form (I), 52 (2.1\%); tuberculoid form (T), 1326 (52.7\%) ; borderline tuberculoid form (BT), $439(17.4 \%)$; borderline lepromatous form (BL), $110(4.4 \%)$; and lepromatous form (L), $590(23.4 \%)$.

\section{Introduction}

In Bangladesh, it is estimated that 150,000 cases of leprosy occur in population of 110 million with a prevalence rate $1.36 / 1000$. Among the estimated cases, so far, 65,000 cases have been registered in different leprosy centres in the country. $13 / 1000$ is the highest prevalence rate in the northern part of the country and $1 / 1000$ is the least prevalence rate in the central part of the country. During the study period (1984-1988), 2517 patients registered in Leprosy Control Institute and Hospital, Mohakhali, Dhaka, for treatment, rehabilitation and follow up. If a large population based study can be done, the total number of estimated cases may be raised.

\section{Materials and Methods}

The materials of this study were all patients with leprosy reported to the Leprosy Control Institute and Hospital, Mohakhali, Dhaka, during the period of 1984-1988. The total number of reported cases was 2517. Medical records available at the out patient department of the hospital were scrutinized and information regarding age, sex, type of disease, deformity, year of registry and area of residents was obtained. $10 \%$ of the cases were detected through voluntary reporting and $90 \%$ were detected through surveys and others (referred by general hospital and medical practitioner). The patients were classified as Indeterminate, tuberculoid, borderline tuberculoid, borderline lepromatous and lepromatous form of leprosy.

\section{Results and Discussion}

This study showed that the number of patients with leprosy registered during the period of 1984-1988 
has slightly increased. A low of 479 patients with leprosy was reported in 1985 and a high of 559 in 1988 (Table 1). The average number of patients reported was 503.4 per year.

Of the total 2517 patients reported with leprosy during 1984 to 1988 in Leprosy Control Insti-tute and Hospital, Mohakhali, Dhaka, 1891 (75.1\%) were males and $626(24.9 \%)$ were females, for a ratio of $3.0: 1$ (Table 2). The distribution of leprosy among male and female on yearly basis was shown in Table 3 . Of these patients, $185(7.4 \%)$ were below 15 years and $2332(92.6 \%)$ were 15 years and over.

(Table 4) '. Among the elder group, maximum age incidence was found to be between $25-45$ years old. The youngest age incidence was 4 years and the oldest was 80 years old. According to type of disease, the tuberculoid type had the highest number of patients $1326(52.7 \%)$ and indeterminate had the lowest number of patients $52(2.1 \%)$; other categories were borderline tuberculoid type, 440 (17.5\%) ; borderline lepromatous type, 109 (4.3\%); lepromatous type, $590(23.4 \%)$; (Table 6).

The distribution of types of leprosy was shown in Table 7 . It showed that there was statistically significant difference in the distribution of leprosy types in male and female. It was found that tuberculoid type was more in female and lepromatous type was more in male. There was no difference in the age distribution between both sexes (Table 5 )

Among the total cases, $302(12 \%)$ cases showed deformity (grade II and III) and it was found in adults. Of these deformities, $250(82.8 \%)$ cases belong to paucibacillary group and $52(17.2 \%)$ cases belong to multibacillary group. There was no deformity in children.

Multidrug therapy (MDT), WHO regimens, was introduced in Bangladesh in 1982 but it was first executed in 1985. At present $54 \%$ of the total detected registered cases throughout Bangladesh were covered with MDT but about $95 \%$ of the patients registered in Leprosy Control Institute and Hospital, Mohakhali, Dhaka, were covered with MDT. Approximate number of performing MDT from 1988 to 2000 in Bangladesh will be $85 \%$ of the total detected registered patients.

With improved health services being offered to the community through the primary health care centres, the leprosy services were integrated with the general health services and primary health care. ${ }^{2.3}$ All categories of health personnel are being gradually trained on leprosy as well as developing awareness in the community through health education. ${ }^{2.3}$

Ealy case detection, registration, treatment, followup patients and their contacts must be enforced rigorously to promote efficient control programmes in the country. ${ }^{2.3}$

Due to limited laboratory facilities for diagnosis of leprosy, the most of the cases were diagnosed based on clinical manifestation. So, well equipped clinical laboratory for more precise diagnosis of diseases include leprosy will be needed in the near future.

\section{Acknowledgements}

I would like to thank Dr. Shinzo Izumi, Director, Department of Bioregulation, National Institute for Leprosy Research, Tokyo, Japan, for his continued advice, encouragement and preparation of the manuscript.

\section{References}

1 "Epidemiology of leprosy in relation to control", 1985, WHO Technical Report Series, 716. pp. 33

2 WHO Expert Committee on Leprosy, Sixth Report, 1988. Technical Report Series, 768. pp. $38-44$

3 A Guide to Leprosy Control, second edition, WHO, 1988. pp. 62-71 
Table 1. Registered cases of leprosy in Leprosy Control Institute and Hospital, Mohakhali, Dhaka. (1984-1988)

\begin{tabular}{|c|c|}
\hline & Patients Registered \\
year & No \\
\hline 1984 & 480 \\
1985 & 479 \\
1986 & 513 \\
1987 & 486 \\
1988 & 559 \\
\hline Total & 2517 \\
\hline
\end{tabular}

Table 2. Distribution of leprosy among male and female. (1984-1988)

\begin{tabular}{ccc} 
Sex & No & $\%$ \\
\hline Male & 1891 & 75.1 \\
Female & 626 & 24.9 \\
\hline Total & 2517 & 100.0 \\
\hline
\end{tabular}

Table 3. Distribution of leprosy among male and female on yearly basis. (1984-1988)

\begin{tabular}{cccccc} 
& \multicolumn{2}{c}{ Male } & \multicolumn{2}{c}{ Female } \\
\cline { 2 - 4 } & No & $\%$ & No & $\%$ & Total \\
\hline 1984 & 377 & 78.5 & 103 & 21.5 & 480 \\
1985 & 348 & 72.7 & 131 & 27.3 & 479 \\
1986 & 384 & 74.9 & 129 & 25.1 & 513 \\
1987 & 371 & 76.3 & 115 & 23.7 & 486 \\
1988 & 411 & 73.5 & 148 & 26.5 & 559 \\
\hline Total & 1891 & 75.1 & 626 & 24.9 & 2517 \\
\hline
\end{tabular}

Table 4. Age distribution in leprosy patients.

(1984-1988)

\begin{tabular}{|c|c|c|}
\hline Age range (years) & No & $\%$ \\
\hline$<15$ & 185 & 7.4 \\
\hline$\geqq 15$ & 2332 & 92.6 \\
\hline Total & 2517 & 100.0 \\
\hline
\end{tabular}

Table 5. Age distribution in male and famale patients. (1984-1988)

\begin{tabular}{ccccc} 
& \multicolumn{2}{c}{ Male } & \multicolumn{2}{c}{ Female } \\
Age range (years) & No & $\%$ & No & $\%$ \\
& 139 & 7.4 & 46 & 7.3 \\
\hdashline 15 & 1749 & 92.6 & 583 & 92.7 \\
\hline Total & 1888 & 100.0 & 629 & 100.0 \\
\hline
\end{tabular}


Table 6. Types of leprosy on yearly basis. (1984-1988)

\begin{tabular}{|c|c|c|c|c|c|c|}
\hline \multirow{2}{*}{ Year } & I & $\mathrm{T}$ & B T & B L & $\mathrm{L}$ & \multirow{2}{*}{ Total } \\
\hline & NO $(\%)$ & NO $(\%)$ & NO (\%) & NO $(\%)$ & NO $(\%)$ & \\
\hline 1984 & $11(2.3)$ & $286(59.6)$ & $62(13.0)$ & $15(3.0)$ & $106(22.1)$ & 480 \\
\hline 1985 & $11(2.3)$ & $243(50.7)$ & $89(18.6)$ & $22(4.6)$ & $114(23.8)$ & 479 \\
\hline 1986 & $12(2.3)$ & $260(50.7)$ & $101(19.7)$ & $25(4.9)$ & $115(22.4)$ & 513 \\
\hline 1987 & $6(1.2)$ & $256(52.7)$ & $88(18.1)$ & $22(4.5)$ & $114(23.5)$ & 486 \\
\hline 1988 & $12(2.1)$ & $281(50.3)$ & $100(17.9)$ & $25(4.5)$ & $141(25.2)$ & 559 \\
\hline Total & $52(2.1)$ & $1326(52.7)$ & $440(17.5)$ & $109(4.3)$ & $590(23.4)$ & 2517 \\
\hline
\end{tabular}

Table 7. Distribution of type of leprosy in male and female. (1984-1988)

\begin{tabular}{cccccccc} 
& I & T & B T & B L & L & \\
Sex & $\ldots \ldots \ldots$ & $\ldots \ldots$ & $\ldots \ldots$ & $\ldots \ldots \ldots$ & Total \\
& NO $(\%)$ & NO (\%) & NO (\%) & NO (\%) & NO (\%) & \\
\hline Male & $23(1.2)$ & $952(50.3)$ & $342(18.1)$ & $86(4.5)$ & $488(25.9)$ & 1891 \\
Female & $29(4.6)$ & $374(59.8)$ & $97(15.5)$ & $24(3.8)$ & $102(16.3)$ & 626 \\
\hline Total & $52(2.1)$ & $1326(52.7)$ & $439(17.4)$ & $110(4.4)$ & $590(23.4)$ & 2517 \\
\hline
\end{tabular}

Note: Differences in the distribution of leprosy types were statistically significant.

$(\mathrm{P}<0.001)$. Lepromatous was more frequent in male and tuberculoid was more frequent in female.

$$
\begin{gathered}
\text { バングラデシュのらい } \\
\text { (1984年-88年 })
\end{gathered}
$$

Agha Masood Choudhury

\section{ダッカらい病院}

1984年から1989年の間に，ダツカ市モハカリにあるらい病院を受診した 2517 人の患者について解析した。男 は1891人(75.1\%)，女は626人 (24.9\%)で，性比はほぶ 3：1であった。年齢別にみると15才以下が $185 人(7.4$

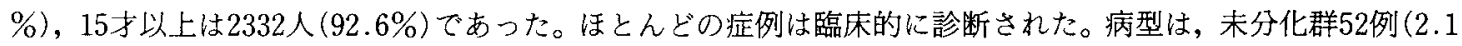
$\%)$ ，数結核型1326例 (52.7\%)，BT439例 (17.4\%)，BL110例 (4.4\%)，らい腫型590例 (23.4\%) であった。 